\title{
Summary of Fast Pyrolysis and Upgrading GHG Analyses
}

\section{LJ Snowden-Swan}

JL Male

December 2012

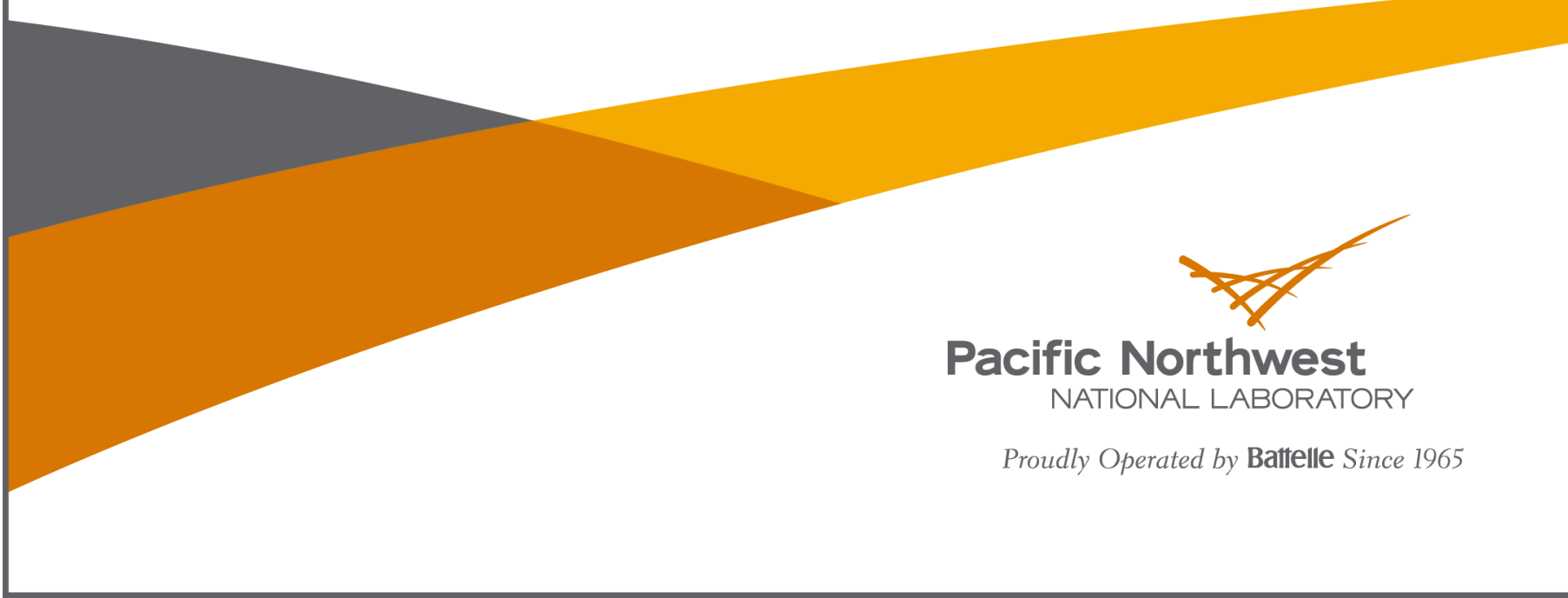




\title{
DISCLAIMER
}

This report was prepared as an account of work sponsored by an agency of the United States Government. Neither the United States Government nor any agency thereof, nor Battelle Memorial Institute, nor any of their employees, makes any warranty, express or implied, or assumes any legal liability or responsibility for the accuracy, completeness, or usefulness of any information, apparatus, product, or process disclosed, or represents that its use would not infringe privately owned rights. Reference herein to any specific commercial product, process, or service by trade name, trademark, manufacturer, or otherwise does not necessarily constitute or imply its endorsement, recommendation, or favoring by the United States Government or any agency thereof, or Battelle Memorial Institute. The views and opinions of authors expressed herein do not necessarily state or reflect those of the United States Government or any agency thereof.

\author{
PACIFIC NORTHWEST NATIONAL LABORATORY \\ operated by \\ BATTELLE \\ for the \\ UNITED STATES DEPARTMENT OF ENERGY \\ under Contract DE-AC05-76RL01830 \\ Printed in the United States of America \\ Available to DOE and DOE contractors from the \\ Office of Scientific and Technical Information, \\ P.O. Box 62, Oak Ridge, TN 37831-0062; \\ ph: (865) 576-8401 \\ fax: $(865) 576-5728$ \\ email: reports@adonis.osti.gov
}

\begin{abstract}
Available to the public from the National Technical Information Service
5301 Shawnee Rd., Alexandria, VA 22312 ph: (800) 553-NTIS (6847)

email: orders@ntis.gov $<$ http://www.ntis.gov/about/form.aspx $>$

Online ordering: http://www.ntis.gov
\end{abstract}

This document was printed on recycled paper. 


\section{Summary of Fast Pyrolysis and Upgrading GHG Analyses}

LJ Snowden-Swan

JL Male

December 2012

Prepared for

the U.S. Department of Energy under Contract DE-AC05-76RL01830

Pacific Northwest National Laboratory

Richland, Washington 99352 



\section{Acknowledgments}

The authors gratefully acknowledge the support of Paul Grabowski, Kristen Johnson, and Alicia Lindauer-Thompson of the U.S. Department of Energy's Energy Efficiency and Renewable Energy Office of Biomass. We would also like to thank David Hsu, Danny Inman, and Eric Tan of the National Renewable Energy Laboratory for providing the preliminary life cycle analysis model used for analysis of the fast pyrolysis and upgrading pathway and for their technical review of this report. In addition, the authors would like to thank Jeongwoo Han, Amgad Elgowainy, Michael Wang and Jennifer Dunn at the Argonne National Laboratory for the integration of PNNL conversion model data into the GREET model. 



\section{Acronyms and Abbreviations}

$\begin{array}{ll}\text { ANL } & \text { Argonne National Laboratory } \\ \text { EISA } & \text { Energy Independence and Security Act } \\ \text { GHG } & \text { greenhouse gas } \\ \text { higher heating value } \\ \text { INL } & \text { Idaho National Laboratory } \\ \text { LCA } & \text { life cycle analysis } \\ \text { LHV } & \text { lower heating value } \\ \text { MYPP } & \text { multi-year program plan } \\ \text { NETL } & \text { National Energy Technology Laboratory } \\ \text { NREL } & \text { National Renewable Energy Laboratory } \\ \text { PNNL } & \text { Pacific Northwest National Laboratory } \\ \text { RFS2 } & \text { Renewable Fuel Standard 2 } \\ \text { SOT } & \text { state-of-technology }\end{array}$





\section{Contents}

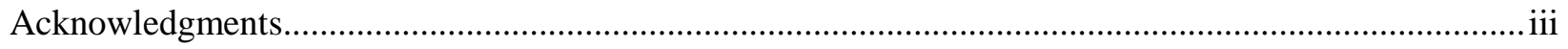

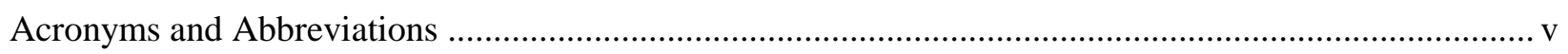

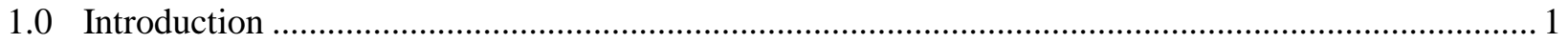

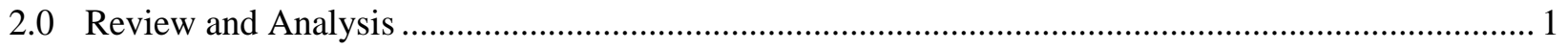

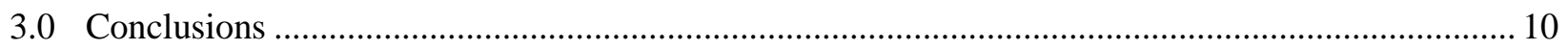

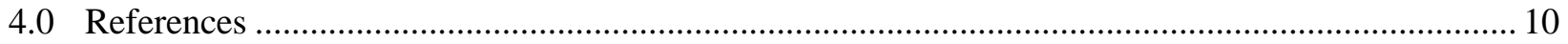




\section{Figures}

Figure 1. Pyrolysis gasoline GHGs, natural gas use, and power consumption (import) for 2017 target case (forest residue) using April 2011 MYPP and November 2011 MYPP assumptions for feedstock moisture, drying, and preprocessing power.

Figure 2. Pyrolysis gasoline GHGs, total fuel yield (gasoline and diesel), and GHG reductions using hybrid poplar (2011-2012 SOT/Projection, 2013-2014 Projection, and 2017 design case)

Figure 3. Pyrolysis gasoline GHGs and natural gas use for fast pyrolysis and upgrading using hybrid poplar. 9

Figure 4. Pyrolysis gasoline GHGs from fast pyrolysis and upgrading using forest residue 9 


\section{Tables}

Table 1. Life Cycle GHG Thresholds Specified in EISA .................................................................. 1

Table 2. Summary of GHG Results for Fast Pyrolysis and Upgrading - Woody Biomass......................... 3

Table 3. Forest Residue Feedstock Moisture and Preprocessing Assumptions ......................................... 4

Table 4. GHG Results for Fast Pyrolysis and Upgrading - Corn Stover................................................ 6

Table 5. GHG Stage Contribution for Fast Pyrolysis and Upgrading - Woody Biomass, $\mathrm{CO}_{2}$ -

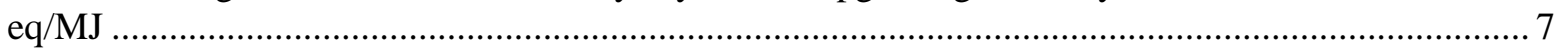





\subsection{Introduction}

The Energy Independence and Security Act (EISA) of 2007 established new renewable fuel categories and eligibility requirements (EPA 2010). A significant aspect of the National Renewable Fuel Standard 2 (RFS2) program is the requirement that the life cycle greenhouse gas (GHG) emissions of a qualifying renewable fuel be less than the life cycle GHG emissions of the 2005 baseline average gasoline or diesel fuel that it replaces. Four levels of reduction are required for the four renewable fuel standards. Table 1 lists these life cycle performance improvement thresholds.

Table 1. Life Cycle GHG Thresholds Specified in EISA

\begin{tabular}{lc}
\hline \multicolumn{1}{c}{ Fuel Type } & Percent Reduction from 2005 Baseline \\
\hline Renewable fuel & $20 \%$ \\
Advanced biofuel & $50 \%$ \\
Biomass-based diesel & $50 \%$ \\
Cellulosic biofuel & $60 \%$ \\
\hline
\end{tabular}

Notably, there is a specialized subset of advanced biofuels that are the cellulosic biofuels. The cellulosic biofuels are incentivized by the Cellulosic Biofuel Producer Tax Credit (26 USC 40) to stimulate market adoption of these fuels. EISA defines a cellulosic biofuel as follows (42 USC 7545(o)(1)(E)):

The term "cellulosic biofuel" means renewable fuel derived from any cellulose, hemicellulose, or lignin that is derived from renewable biomass and that has lifecycle greenhouse gas emissions, as determined by the Administrator, that are at least 60 percent less than the baseline lifecycle greenhouse gas emissions.

As indicated, the Environmental Protection Agency (EPA) has sole responsibility for conducting the life cycle analysis (LCA) and making the final determination of whether a given fuel qualifies under these biofuel definitions. However, there appears to be a need within the LCA community to discuss and eventually reach consensus on discerning a 50-59\% GHG reduction from a $\geq 60 \%$ GHG reduction for policy, market, and technology development. The level of specificity and agreement will require additional development of capabilities and time for the sustainability and analysis community, as illustrated by the rich dialogue and convergence around the energy content and GHG reduction of cellulosic ethanol (an example of these discussions can be found in Wang 2011).

GHG analyses of fast pyrolysis technology routes are being developed and will require significant work to reach the levels of development and maturity of cellulosic ethanol models. This summary provides some of the first fast pyrolysis analyses and clarifies some of the reasons for differing results in an effort to begin the convergence on assumptions, discussion of quality of models, and harmonization.

\subsection{Review and Analysis}

Recently, several organizations have undertaken LCAs of GHGs for biofuels from the fast pyrolysis of biomass and upgrading of bio-oil. The results of these LCAs are summarized in Table 2. Directly 
comparable results for forest residue are highlighted in red in row 1 (Pyrolysis Gasoline GHG Emissions) and row 5 (Reduction from Baseline) of Table 2. These results range from 62-68\% reduction in GHG emissions from the petroleum baseline. 
Table 2. Summary of GHG Results for Fast Pyrolysis and Upgrading - Woody Biomass

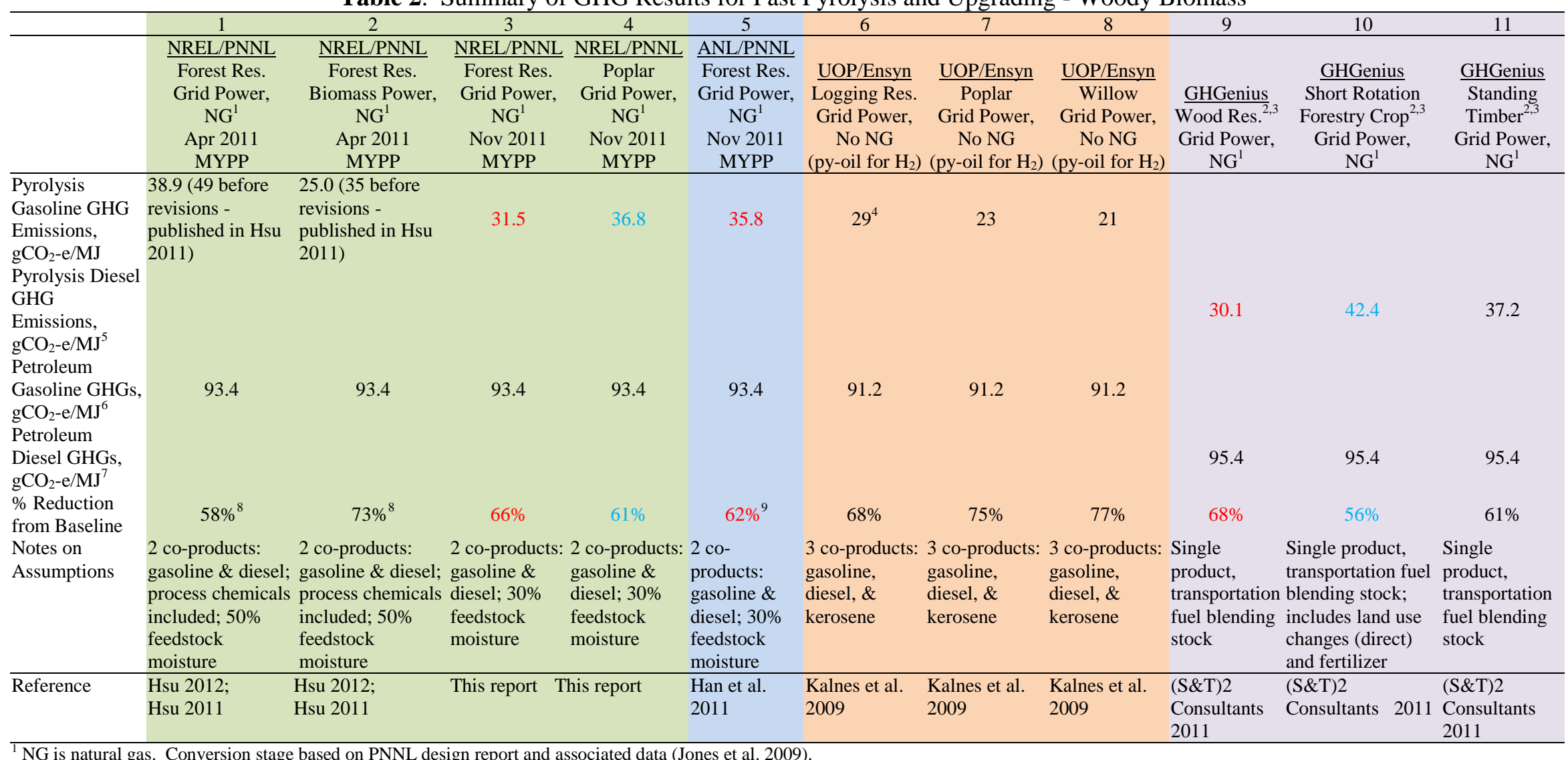

${ }^{1} \mathrm{NG}$ is natural gas. Conversion stage based on PNNL design report and associated data (Jones et al. 2009).

${ }^{2}$ GHGenius results are originally presented in higher heating value (HHV) and converted to lower heating value (LHV) (using HHV/LHV=1.07).

${ }^{3}$ GHGenius presents results for combined gasoline and diesel fuels, and compares them to conventional petroleum diesel fuel.

${ }_{5}^{4}$ Higher because of longer transportation distances assumed for logging residue. No feedstock chemicals or growing inputs, however.

${ }_{6}^{5}$ Diesel results are generally representative of the gasoline results and therefore are not presented for all of the studies.

${ }^{6}$ The GREET 2005 conventional gasoline baseline is $93.4 \mathrm{gCO}_{2}$-e/MJ (486 $\mathrm{gCO}_{2}$-e/mile). The National Energy Technology Laboratory (NETL) gasoline baseline is $96.3 \mathrm{~g} / \mathrm{MJ}-\mathrm{LHV}$ (Skone and Gerdes 2009$)$.

The UOP/Ensyn and GHGenius studies have also evaluated petroleum baseline GHGs and are listed in the corresponding columns.

${ }^{7}$ The GREET 2005 conventional diesel baseline is $96.3 \mathrm{~g} \mathrm{CO}_{2}$-e/MJ (416 $\mathrm{g} \mathrm{CO}_{2}$-e/mile). The NETL baseline for diesel is 95.0 g/MJ-LHV (Skone and Gerdes 2009). The UOP/Ensyn and GHGenius studies have also evaluated petroleum baseline GHGs and are listed in the corresponding columns.

${ }^{8}$ The GREET 2005 conventional gasoline baseline is $93.4 \mathrm{gCO}_{2}$-e/MJ and $302 \mathrm{~g} \mathrm{CO}_{2}$-e/ $/ \mathrm{km}\left(486 \mathrm{gCO}_{2}\right.$-e/mile). NREL compares their final result per distance travelled on pyrolysis gasoline, $117 \mathrm{gCO}{ }_{2}$-e/ $/ \mathrm{km}^{2}$ $\left(188 \mathrm{gCO}_{2}\right.$-e/mile), to the reference value and reports a $61 \%$ reduction. However, NREL assumes a fuel economy of $25.4 \mathrm{mpg}$, instead of what GREET uses as the 2005 value, $23.4 \mathrm{mpg}$. Therefore, when comparing NREL's g/MJ value to the GREET baseline, NREL obtains $58 \%$, but when comparing on the basis of g/mile, NREL obtains $61 \%$. This is an inconsistency to be aware of and that merits resolution at a later date. One way to make a change would be to change the fuel economy to 2005 standards, or recalculate the GREET baseline for $\mathrm{g} / \mathrm{mile}$, using the $25.4 \mathrm{mpg}$.

${ }^{9}$ Current default case included in GREET 2011 for forest residue pyrolysis gasoline uses an external $\mathrm{H}_{2}$ source, and therefore has higher GHG emissions and lower emission reductions relative to the case presented here $(55 \%)$ 
Initially, the National Renewable Energy Laboratory (NREL) published a study in April 2011 (Hsu 2011) using conversion data provided by Pacific Northwest National Laboratory (PNNL) from the 2017 design case (Jones et al. 2009). Shortly thereafter, NREL and PNNL worked together to refine the LCA model, resulting in several revisions to the model and GHG results. These results (both before and after the revisions) are given in Table 2, column 1, and NREL recently published them in a journal article (Hsu 2012). NREL also evaluated a biomass-based electricity case, shown in Table 2, column 2. Cases given in columns 1 and 2 assumed feedstock moisture and preprocessing power from the U.S. Department of Energy's April 2011 Biomass Multi-Year Program Plan (MYPP) (DOE 2011a), which are listed in Table 3.

Meanwhile, Argonne National Laboratory (ANL) conducted a study (Han et al. 2011) also using conversion data provided by PNNL for the 2017 design case. In addition, PNNL provided the new assumptions used for the November 2011 Biomass MYPP (DOE 2011b) technical tables for feedstock moisture content and preprocessing power developed by Idaho National Laboratory (INL), as shown in Table 3. The results from ANL's study are given in Table 2, column 5. Table 3 compares the new feedstock assumptions (included in the November 2011 MYPP) with the previous assumptions from the April 2011 MYPP. PNNL helped thoroughly review and refine the conversion data used for ANL's GREET model $^{1}$ (ANL 2011) at a one-day meeting at ANL and in follow-up correspondence prior to the rollout of the updated version of GREET.

Table 3. Forest Residue Feedstock Moisture and Preprocessing Assumptions

\begin{tabular}{lcc}
\hline & Old Front-End & New Front-End \\
& (Apr. 2011 MYPP) & (Nov. 2011 MYPP) \\
\hline Feedstock Moisture & $50 \%$ & $30 \%$ \\
Feedstock Moisture after Drying & $7 \%$ & $10 \%$ \\
Grinding and Drying (Fan) Power, MW & 8.1 & 4.8 \\
Process Offgas used for H2, lb/hr & 4,902 & 10,863 \\
\hline
\end{tabular}

PNNL then updated the revised NREL SimaPro model for the forest residue 2017 design case with INL's new preprocessing assumptions (see Table 2, column 3). Figure 1 shows the gasoline GHG emissions, natural gas usage, and electricity usage (per megajoule of gasoline and diesel fuel produced) for the 2017 design case using the April 2011 and November 2011 MYPP feedstock assumptions. The new feedstock moisture and drying assumptions result in lower drying energy and, ultimately, lower natural gas usage and associated GHG emissions for the system. This is because less system offgas (approximately 10 times less) is required to provide heat for feedstock drying (in addition to that from char combustion), and the offgas can instead be used to replace natural gas in the hydrogen plant. In addition, the new lower estimates for feedstock grinding and drying result in lower electricity requirements and hence lower related GHG emissions.

\footnotetext{
${ }^{1}$ More information on the GREET model can be found at http://greet.es.anl.gov.
} 


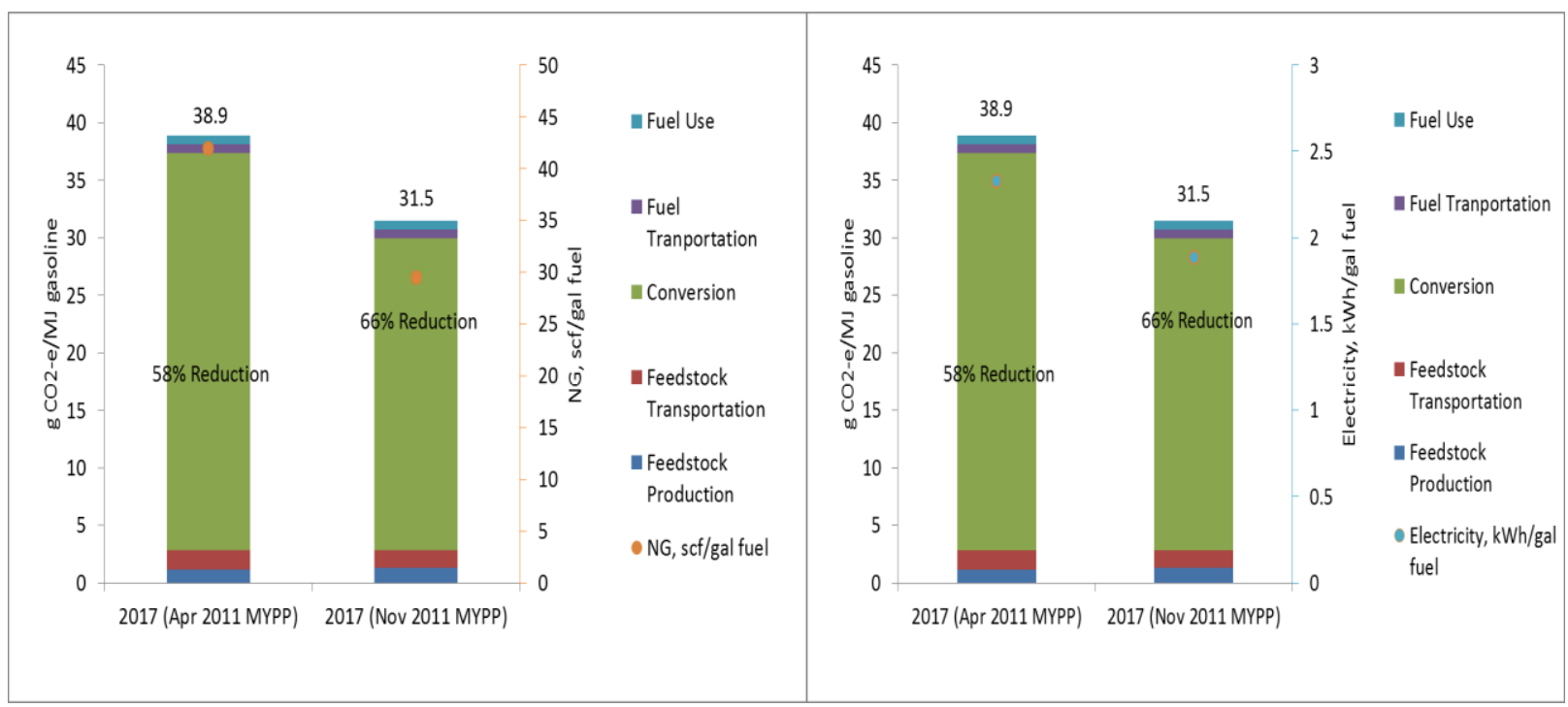

Note: Conversion stage includes feedstock preprocessing. Percent reduction is relative to GREET 2005 petroleum gasoline baseline, $93.4 \mathrm{gCO}_{2}$-e/MJ.

Figure 1. Pyrolysis gasoline GHGs, natural gas use, and power consumption (import) for 2017 target case (forest residue) using April 2011 MYPP and November 2011 MYPP assumptions for feedstock moisture, drying, and preprocessing power.

PNNL also recently modeled the 2017 design case with hybrid poplar, the feedstock assumed for the pathway in the November 2011 MYPP. The resulting GHG emissions from this analysis are given in Table 2, column 4. Emissions for hybrid poplar are higher than those for forest residue because the energy required for cultivation and harvesting of a purpose-grown crop does not apply to a waste product such as forest residue. Poplar cultivation and harvesting inventory for this model was developed by NREL, based on data for short rotation willow from the literature (Inman 2012; Abrahamson et al. 2002; Felix et al. 2008; Hartsough and Spinelli 2002; Spinelli and Hartsough 2006; Volk T. 2010). However, the energy consumption values for harvesting equipment (feller, skidder, delimber, and chopper) were revised using data from INL (Searcy and Hess 2010). Energy for transportation and handling were assumed to be the same as in the NREL/PNNL study of forest residue (Table 2, column 3).

Other studies of life cycle GHGs for fuels from fast pyrolysis and upgrading using woody biomass include those by UOP/Ensyn (Kalnes et al. 2009) and the Canadian LCA model GHGenius ((S\&T) ${ }^{2}$ Consultants 2011). UOP/Ensyn studied their rapid thermal processing (RTP) process using three different woody feedstocks (Kalnes et al. 2009), the results of which are given in Table 2, columns 6-8. It is important to note that for these cases, UOP/Ensyn assumes no natural gas consumption, but instead a cut of pyrolysis oil is used to provide all upgrading hydrogen, which may at least partially account for the lower GHGs relative to the other studies. The publication (a presentation) for this study provides limited details, and it is not clear as to what feedstock moisture is assumed. GHGenius also analyzes three woody feedstocks (GHGenius 2011; (S\&T) ${ }^{2}$ Consultants 2011), using data provided by Ensyn for the fast pyrolysis process and PNNL data (Jones et al. 2009) for the upgrading process. The GHGenius results (Table 2, columns 9-11) are provided for the composite gasoline/diesel fuel and are compared to conventional petroleum diesel in the report.

ANL also analyzed fast pyrolysis and upgrading fuels from corn stover feedstock using conversion data from a recent NREL report, the results of which are presented in Table 4 (Wright et al. 2010). 
Similar to the UOP/Ensyn process, this study considers a case where a cut of the pyrolysis oil is used to provide hydrogen for hydrotreating and hydrocracking, thereby avoiding fossil GHG emissions associated with steam reforming of natural gas and greatly reducing the fuel's carbon footprint. It should be noted that process technology for reforming of bio-oils is still in the early stages of development.

Table 4. GHG Results for Fast Pyrolysis and Upgrading - Corn Stover

\begin{tabular}{lcc}
\hline & $\begin{array}{c}\text { ANL (GREET) - Corn Stover, } \\
\text { Grid Electricity and } \mathrm{NG}^{1}\end{array}$ & $\begin{array}{c}\text { ANL (GREET) - Corn Stover, } \\
\text { Grid Electricity and Py-oil for } \mathrm{H}_{2}{ }^{1}\end{array}$ \\
\hline $\begin{array}{l}\text { Pyrolysis Gasoline GHG Emissions, } \\
\mathrm{gCO}_{2} \text {-e/MJ }\end{array}$ & 30.3 & 13.2 \\
Petroleum Gasoline Baseline GHGs, & 93.4 & 93.4 \\
$\mathrm{gCO}_{2}$-e/MJ $\mathrm{MJ}^{2}$ & $68 \%$ & $86 \%$ \\
$\%$ Reduction from Baseline & & \\
\hline $\begin{array}{l}\text { I Conversion stage based on design by Iowa State, ConocoPhillips, and NREL (Wright et al. 2010). } \\
{ }^{2} \text { The GREET 2005 conventional gasoline baseline is } 93.4 \mathrm{gCO}_{2} \text {-e/MJ }\left(486 \mathrm{gCO}_{2} \text {-e/mile). }\right.\end{array}$ & \\
\hline
\end{tabular}

Results from analyses having similar assumptions for feedstock type and the conversion process are the most comparable and are shown in red in Table 2. These include the forest residue cases from the NREL/PNNL (column 3), ANL/PNNL (column 5), and GHGenius (column 9) models. These studies all assume a forest residue feedstock, the use of grid electricity, and the use of supplemental natural gas for hydrogen. (The NREL/PNNL study using April 2011 MYPP feedstock assumptions is excluded in lieu of the updated version.) GHG reductions from the petroleum baseline range from $62-68 \%$ for these studies. The differences between the estimates may be partially explained by breaking out the GHG contributions by stage of the fuel supply chain, as shown in Table 5. Note the ANL/PNNL values for individual stage contribution were estimated from graphical results (Han et al. 2011). The ANL/PNNL, NREL/PNNL, and GHGenius analyses for forest/logging residue (Table 5, columns 1-3) have similar fuel production stage GHGs; however, GHGs for feedstock production and transportation vary significantly. Estimates for the feedstock production stage range from 0-1.4 $\mathrm{gCO}_{2}-\mathrm{e} / \mathrm{MJ}$ and for feedstock transportation from 0.9-4.8 $\mathrm{gCO}_{2}$-e/MJ. (NREL's value for fuel distribution, $0.7 \mathrm{~g} \mathrm{CO}_{2}$-e/MJ, was assumed for the ANL/PNNL analysis and was subtracted from the aggregate $5.7 \mathrm{~g} \mathrm{CO}_{2}$-e/MJ for transportation.) Although these stages are relatively small contributors to the overall carbon footprint, differing assumptions for them can affect whether or not the fuel would qualify as "cellulosic" (60\% or greater GHG reduction from petroleum baseline). 
Table 5. GHG Stage Contribution for Fast Pyrolysis and Upgrading - Woody Biomass, $\mathrm{CO}_{2}$-eq/MJ

\begin{tabular}{|c|c|c|c|}
\hline & $\begin{array}{c}\text { ANL/PNNL }{ }^{1} \\
\text { Forest } \\
\text { Residue, } \\
\text { Grid } \\
\text { Electricity } \\
\text { and NG } \\
\text { (Nov 2011 } \\
\text { MYPP) }\end{array}$ & $\begin{array}{c}\text { NREL/PNNL } \\
\text { Forest } \\
\text { Residue, } \\
\text { Grid } \\
\text { Electricity } \\
\text { and NG } \\
\text { (Nov 2011 } \\
\text { MYPP) }\end{array}$ & $\begin{array}{c}\text { GHGenius } \\
\text { Wood } \\
\text { Residues, } \\
\text { (Canadian) } \\
\text { Grid } \\
\text { Electricity }^{2}\end{array}$ \\
\hline $\begin{array}{l}\text { Feedstock Chemicals } \\
\text { (fertilizer, herbicide) }\end{array}$ & 0 & 0 & 0 \\
\hline Feedstock Production & 1.4 & 1.3 & 0 \\
\hline Feedstock Transport & $5.5^{3}$ & 1.6 & 0.9 \\
\hline Fuel Production & 28.1 & 27.1 & 27.3 \\
\hline Fuel Transport & & 0.7 & $0.9^{4}$ \\
\hline Fuel Combustion & 0.8 & 0.8 & 1.1 \\
\hline Total & 35.8 & 31.5 & 30.1 \\
\hline \multicolumn{4}{|c|}{$\begin{array}{l}{ }^{1} \text { Estimated from graphical data (Han et al. 2011, Fig. 20). } \\
{ }^{2} \text { Results are presented for "Refined Bio-Oil," combined gasoline and diesel } \\
\text { fractions. } \\
{ }^{3} \text { Includes feedstock and fuel transportation. } \\
{ }^{4} \text { Includes fuel dispensing, which is typically not included in other studies }\end{array}$} \\
\hline
\end{tabular}

Results in Table 2 shown in blue (columns 4 and 10) can also be appropriately compared. These results are for hybrid poplar feedstock (corresponding to the MYPP pathway) and a short rotation forestry crop, showing GHG reductions of $61 \%$ and $56 \%$ from the petroleum baseline, respectively. The remaining GHG estimates listed in Table 2 are not appropriately comparable to those previously discussed because they have significantly different assumptions regarding feedstock or feedstock conditions (as with cases in columns 1 and 10) or fuel sources for conversion (as with the NREL biomass power case in column 2 and the UOP/Ensyn cases that use pyrolysis oil for hydrogen generation).

Power and natural gas usage contribute the majority of GHGs to the fuel cycle (approximately $85 \%$ for the NREL/PNNL forest residue case, Table 2, column 3) and as such are critical to the analyses. The UOP/Ensyn study assumes a cut of bio-oil can be used to provide all hydrogen. As expected, this option results in lower conversion stage GHG emissions, but naturally at the cost of product yield. PNNL is involved in evaluations of both the economics and the GHGs of a modified version of the 2017 design case that uses pyrolysis oil instead of natural gas for hydrogen generation. Of particular interest is the identification of a "sweet spot," where both economics are favorable and GHG reductions are maximized.

To further illustrate the trade-off between GHGs and yield for this fuel pathway, Figure 2 shows results for the 2017 design case (Table 2, column 4), along with the 2011-2012 State-of-Technology (SOT)/Projection and 2013-2014 Projection cases. These cases are for hybrid poplar feedstock and correspond to the design and economics presented in the November 2011 MYPP. Advances in the technology over time are assumed to increase pyrolysis oil and product fuel yields from the current SOT to the target case. As fuel yields increase, lower amounts of offgas and char are available for hydrogen generation and heat and power generation, and higher yields of bio-oils require additional amounts of hydrogen for upgrading, both factors thereby increasing natural gas consumption and associated GHG emissions. Figure 3 shows the change in natural gas consumption. Plant power on an absolute basis is 13.0, 15.9, and 18.3 MW for the 2011-2012, 2013-2014, and 2017 cases, respectively. This increasing trend is the result of higher amounts of power for hydrogen compression (because more fuel is being 
made) and lower amounts of heat from char available for steam and electricity generation. Note that power consumption per unit of fuel energy produced stays relatively constant over time because the same amount of hydrogen is used per unit of fuel produced (compression for which is the primary power consumer at the plant).

Use of forest residue is of particular interest for biofuel production because it is considered a waste product, and as such does not have the GHG emissions burdens of cultivating and harvesting a purposegrown crop. Figure 4 shows life cycle GHGs using forest residue feedstock for the 2017 goal case (Table 2, column 3), along with the 2011-2012 and 2013-2014 projection cases. Note that this analysis assumes the same transportation distance ( 45 miles) for forest residue and hybrid poplar. This may not be the case in reality, as forest residue is expected to require a larger collection radius compared with farmed trees.

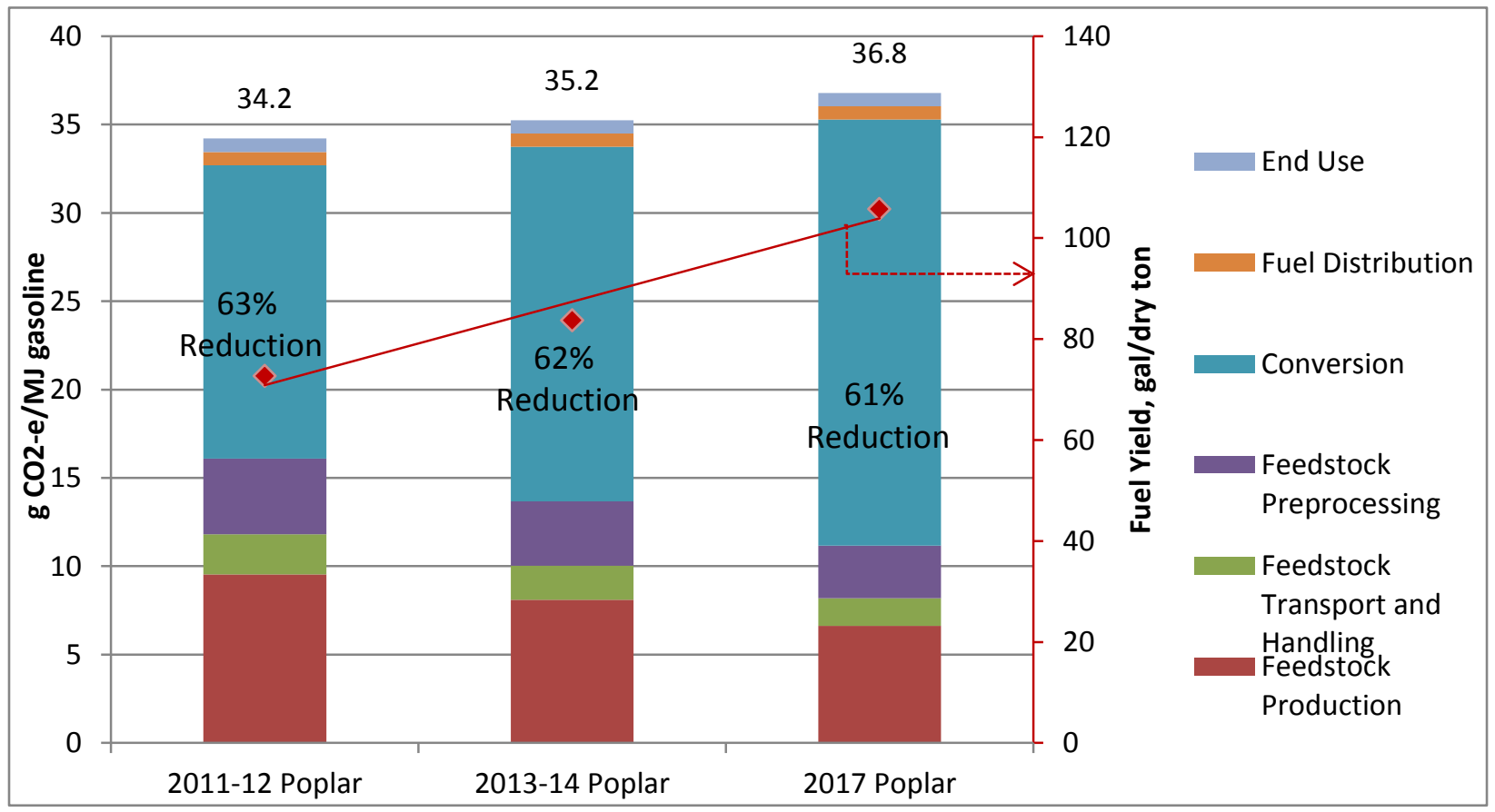

Note: Percent reduction is relative to GREET 2005 petroleum gasoline baseline, $93.4 \mathrm{gCO}_{2}$-e/MJ.

Figure 2. Pyrolysis gasoline GHGs, total fuel yield (gasoline and diesel), and GHG reductions using hybrid poplar (2011-2012 SOT/Projection, 2013-2014 Projection, and 2017 design case). 


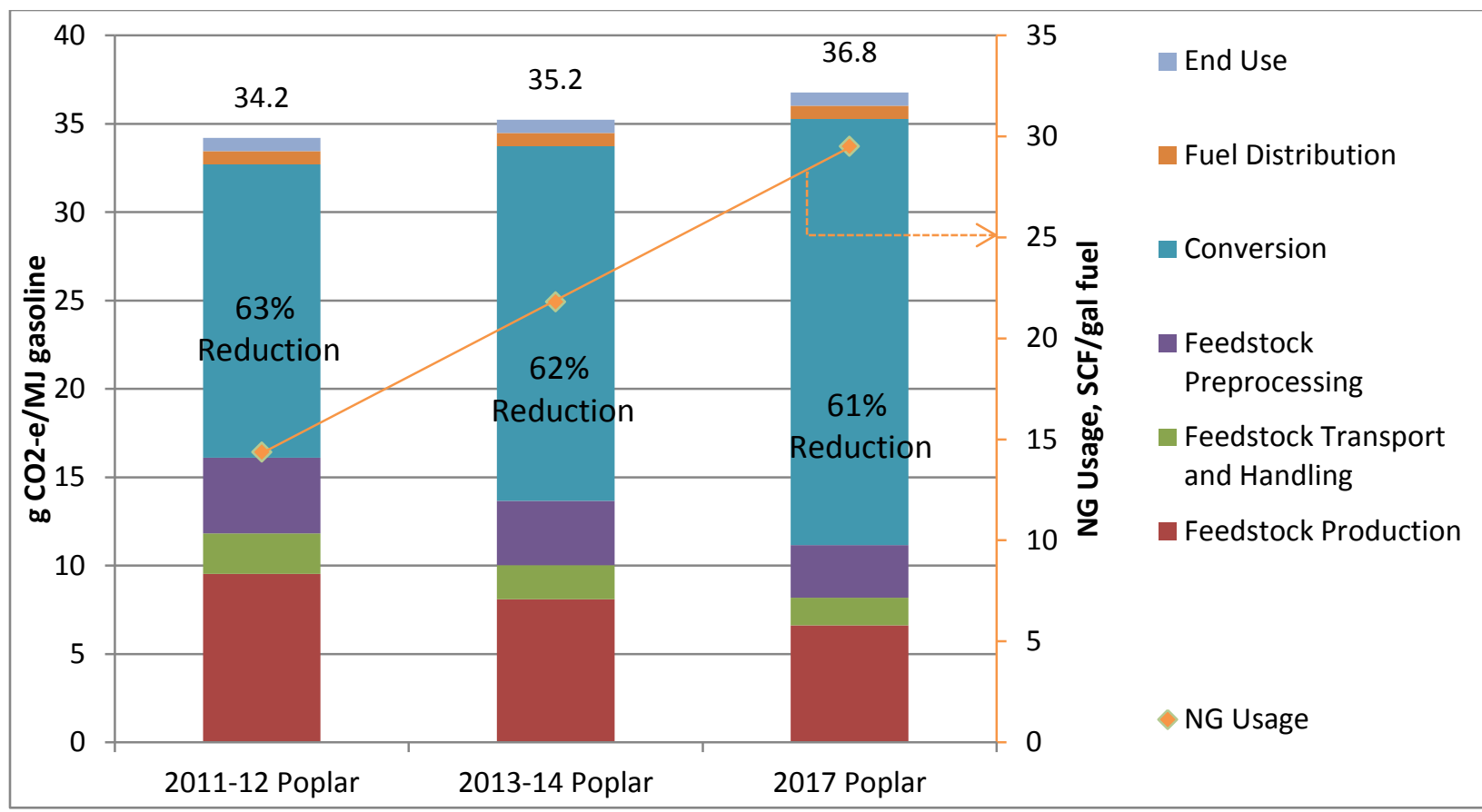

Note: Percent reduction is relative to GREET 2005 petroleum gasoline baseline, $93.4 \mathrm{gCO}_{2}-\mathrm{e} / \mathrm{MJ}$.

Figure 3. Pyrolysis gasoline GHGs and natural gas use for fast pyrolysis and upgrading using hybrid poplar.

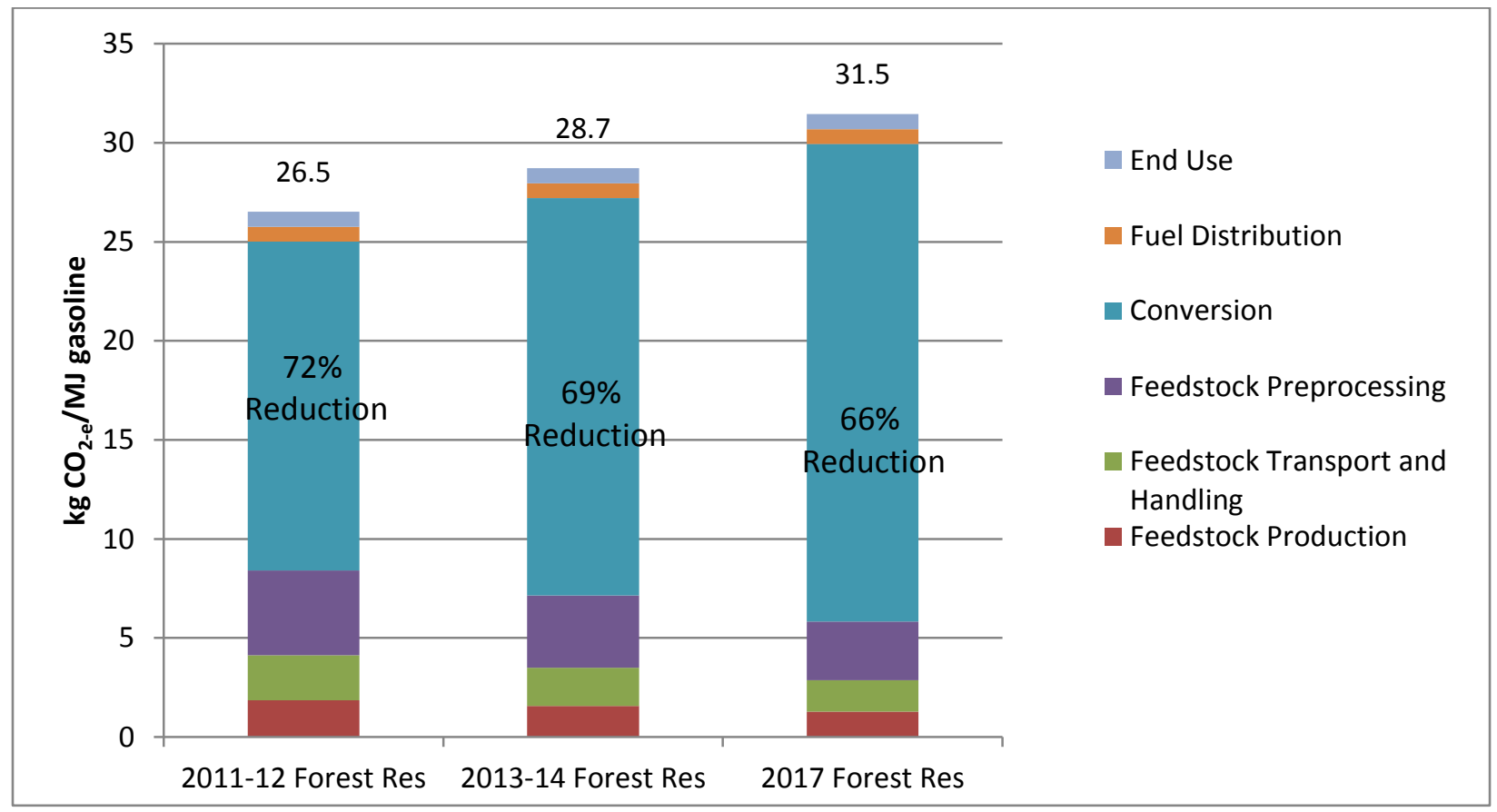

Note: Percent reduction is relative to GREET 2005 petroleum gasoline baseline, $93.4 \mathrm{gCO}_{2}$-e/MJ.

Figure 4. Pyrolysis gasoline GHGs from fast pyrolysis and upgrading using forest residue. 


\subsection{Conclusions}

From this initial review of recent GHG studies, the average value of estimates for forest residue (from the ANL/PNNL, NREL/PNNL, and GHGenius models) is $32.5 \mathrm{gCO}_{2-\mathrm{e}} / \mathrm{MJ}$, or a $65 \%$ reduction from the GREET 2005 petroleum gasoline baseline value (93.4 gCO2-e/MJ). Although these results indicate this fuel to be within the cellulosic biofuel definition range, only the EPA can make the final determination on whether this pathway qualifies under the EISA advanced or cellulosic definitions. Fewer estimates are available for hybrid poplar, though it is evident that GHG reductions will be less for a short rotation woody crop than a residue feedstock. However, further work on convergence in the larger community and clarification of the variance associated with the models would help clarify the GHG reduction classification boundary.

Technology advances that improve fuel yields may not always decrease GHG emissions, and in this specific instance may lead to higher GHG emissions, but may still be within the range of EISA's cellulosic biofuel definition. Reduced-fossil or non-fossil options, such as using biomass for power and hydrogen, will further reduce net GHGs for this pathway. However, the balance between economics (strongly influenced by yield) and GHGs needs to be fully understood and optimized. In addition, the technical feasibility of processes such as bio-oil reforming needs to be determined. Another important consideration is that the design case will be updated in the near future and will likely integrate new research on alternative approaches to direct liquefaction of biomass with processes including but not limited to catalytic pyrolysis, hydropyrolysis, and hydrothermal liquefaction. The revised design could therefore change significantly from its current state. Even with these changes, the balance between fuel product yield and GHGs will remain critical to the development and implementation of sustainable biofuels and is a key component of PNNL's analysis work for FY12 and beyond.

\subsection{References}

42 USC 7545. 2007. Energy Independence and Security Act. Public Law 110-140.

20 USC 40. 2008. Food, Conservation, and Energy Act. Public Law 110-234.

Abrahamson L, T Volk, R Kopp, E White, and J Ballard. 2002. Willow Biomass Producers Handbook, January 2002. State University of New York College of Environmental Science and Forestry, Syracuse, New York.

ANL - Argonne National Laboratory. 2011. GREET Model, the Greenhouse Gas, Regulated Emissions, and Energy Use in Transportation Model, version GREET_2011, Argonne, Illinois.DOE - U.S. Department of Energy. 2011a. Biomass Multi-Year Program Plan-April 2011. U.S. Department of Energy, Energy Efficiency and Renewable Energy, Office of Biomass Program. Washington, DC. Accessed March 30, 2012 at http://www1.eere.energy.gov/biomass/pdfs/mypp april 2011.pdf.

DOE - U.S. Department of Energy. 2011a. Biomass Multi-Year Program Plan-November 2011. U.S. Department of Energy, Energy Efficiency and Renewable Energy, Office of Biomass Program.

Washington, DC. Accessed March 30, 2012 at

http://www1.eere.energy.gov/biomass/pdfs/mypp_november_2011.pdf. 
EPA - U.S. Environmental Protection Agency. 2010. EPA Regulatory Announcement, EPA Finalizes Regulations for the National Renewable Fuel Standard Program for 2010 and Beyond. EPA-420-F-10007, Washington, D.C.

Felix E, DR Tilley, G Felton, and E Famino. 2008. "Biomass production of hybrid poplar (Populus sp.) grown on deep-trenched municipal biosolids." Ecological Engineering 33(1):8-14.

GHGenius. 2011. GHGenuis Model version 4.0. Accessed March 30, 2012 at http://www.ghgenius.ca/downloads.php.

Han J, A Elgowainy, I Palou-Rivera, JB Dunn, and MQ Wang. 2011. Well-to-Wheels Analysis of Fast Pyrolysis Pathways with GREET. Energy Systems Division, Argonne National Laboratory, Argonne, Illinois.

Hartsough BR and R Spinelli. 2002. Productivities and Costs of Short-Rotation Woody Crops Harvesting Technologies: Projections for American Plantations. Oak Ridge National Laboratory, Oak Ridge, Tennessee, p. 53.

Hsu D. 2011. Life Cycle Assessment of Gasoline and Diesel Produced via Fast Pyrolysis and Hydroprocessing. NREL/TP-6A20-49341, prepared for the U.S. Department of Energy by National Renewable Energy Laboratory, Golden, Colorado.

Hsu D. 2012. "Life cycle assessment of gasoline and diesel produced via fast pyrolysis and hydroprocessing." Biomass and Bioenergy 45:41-47.

Inman D. 2012. Meeting between Lesley Snowden-Swan (Pacific Northwest National Laboratory) and Daniel Inman (National Renewable Energy Laboratory, Golden, Colorado), February 8, 2012, Richland Washington.

Jones SB, JE Holladay, C Valkenburg, DJ Stevens, C Walton, C Kinchin, DC Elliott, S Czernik. 2009. Production of Gasoline and Diesel from Biomass via Fast Pyrolysis, Hydrotreating and Hydrocracking: A Design Case. PNNL-18284, Rev. 1, prepared for the U.S. Department of Energy by Pacific Northwest National Laboratory, Richland, Washington.

Kalnes T, G Hopkins, M Reno, and D Shonnard. 2009. "Envergent Biofuel Technology and Life Cycle Assessment," presented at the 2009 International Conference TC Biomass Conversion Science,

September 16-18, Chicago, Illinois.

$(\mathrm{S} \& \mathrm{~T})^{2}$ Consultants. 2011. The Addition of Pyrolysis Oil Pathways to GHGenius. Prepared for Natural Resources Canada by (S\&T) ${ }^{2}$ Consultants, Inc., Delta, British Columbia, Canada.

Searcy E and J Hess. 2010. Uniform-Format Feedstock Supply System: A Commodity-Scale Design to Produce an Infrastructure-Compatible Biocrude from Lignocellulosic Biomass (DRAFT). INL/EXT-1020372, Rev. 0, prepared for the U.S. Department of Energy by the Idaho National Laboratory, Idaho Falls, Idaho.

Skone T and K Gerdes. 2009. Development of Baseline Data and Analysis of Life Cycle Greenhouse Gas Emissions of Petroleum-Based Fuels. DOE/NETL-2009/1346, National Energy Technology Laboratory, Morgantown, West Virginia. 
Spinelli R and BR Hartsough. 2006. "Harvesting SRF Poplar for Pulpwood: Experience in the Pacific Northwest." Biomass and Bioenergy 30(5):439-445.

Volk T. 2010. Personal communication between Daniel Inman (National Renewable Energy Laboratory, Golden, CO) and Timothy Volk (State University of New York, Syracuse, NY) regarding a review of SRC willow processes, 2010.

Wang MQ, J Han, Z Haq, WE Wallace, M Wu, and A Elgowainy. 2011. "Energy and greenhouse gas emission effects of corn and cellulosic ethanol with technology improvements and land use changes." Biomass and Bioenergy 35(5):1885-1896.

Wright M, J Satrio, R Brown, D Daugaard, and D Hsu. 2010. Techno-Economic Analysis of Biomass Fast Pyrolysis to Transportation Fuels. NREL/TP-6A20-46586, prepared for the U.S. Department of Energy by the National Renewable Energy Laboratory, Golden, Colorado. 


\section{Distribution}

No. of

Copies

\# Name

Organization

Address

City, State and ZIP Code

\# Organization

Address

City, State and ZIP Code

Name

Name

Name

Name

Name (\#)

\# Name

Organization

Address

City, State and ZIP Code
No. of

\section{Copies}

\# Foreign Distribution

\# Name

Organization

Address

Address line 2

COUNTRY

\# Local Distribution

Pacific Northwest National Laboratory

Name

Name

Mailstop

Mailstop

Name

Mailstop

Name

Mailstop

Name

(PDF) 




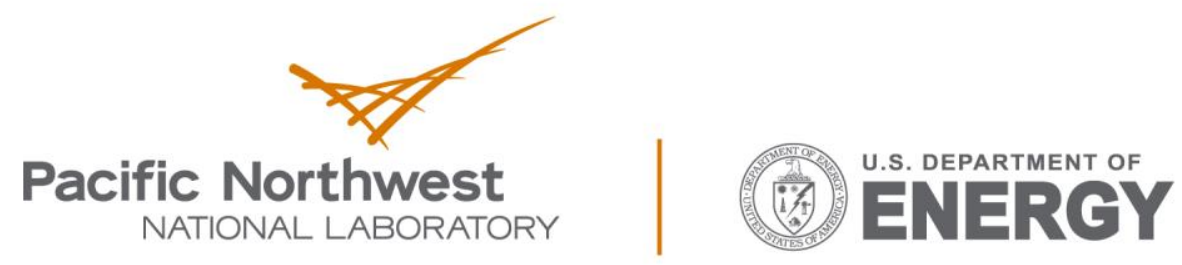

Proudly Operated by Battelle Since 1965

902 Battelle Boulevard

P.O. Box 999

Richland, WA 99352

1-888-375-PNNL (7665)

www.pnnl.gov 